\title{
J
}

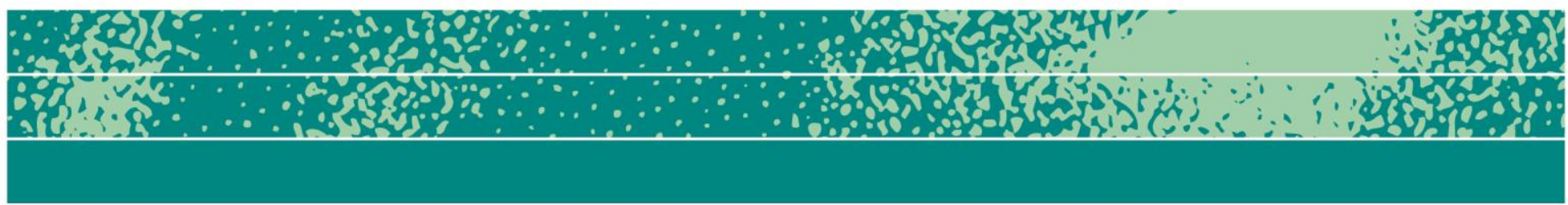

Essay

\section{Conditions of Creativity: Adding Historical Perspective}

John McCreery (The Word Works, Ltd. jlm@wordworks.jp)

\section{Beyond the Ethnographic Present}

A Google search for "creativity" takes 0.54 seconds to produce 220 million hits. A search for "creativity" on Amazon.com discovers 25,156 books. The same search on Slideshare produces links to 115,791 presentations. What can anthropologists and business anthropologists, in particular, bring to this conversation?

One answer is ethnography, the close study of creativity in specific contexts where the anthropologist adds insights from anthropological theory to participant-observation and native exegesis. Ethnography based on intensive fieldwork can produce compelling accounts that ring true, to industry insiders as well as to those who conduct similar studies (see, for example, Moeran 1996, McCreery 2001, Moeran and Christensen, ed., 2014).

However, as Clifford Geertz observed in his introduction to Islam Observed (1968), the value of ethnographic insights depends on larger conversations. And today these conversations are more widespread. As Marcus and Fischer (1999: xx) have famously noted, anthropologists no longer enjoy the privilege of traveling to places unknown to their readers or writing an ethnography that becomes an authoritative account: "Rather we step into a stream of already existing representations
Page 1 of 11

JBA 5(1): 105-115

Autumn 2016

(C) The Author(s) 2016 ISSN 2245-4217

www.cbs.dk/jba 
produced by journalists, prior anthropologists, historians, creative writers, and of course the subjects of study themselves."

For business anthropologists, this predicament is particularly poignant. Our clients and our readers include industry insiders, individuals whose knowledge and experience may far exceed our own. We are fortunate, then, when our resources include an active trade press, a resource I discovered while working and doing research in Japan.

\section{Ethnography Enlarged}

The focus of my current research is the advertising industry in Japan. My wife and I moved to Japan in 1980. In 1983, I was hired as an Englishlanguage copywriter by Hakuhodo, Inc., Japan's second largest advertising agency, where, as a copywriter in Hakuhodo's international division I was a frog at the bottom of a narrow well. Hakuhodo is a very large company, with roughly three thousand employees. I worked on dozens of projects with a great variety of people. Was what I observed and what I was told by my colleagues typical of advertising in Japan? How could I possibly tell?

The answer is both simple and overwhelming. Japan's advertising industry is covered by a large and active trade press. Every month, just two of its most prominent publications, Sendenkaigi [Publicity Forum] and BRAIN, publish four hundred information-packed pages of industry news and commentary. Choosing what to include in my notes is like standing in front of a firehose and trying to select the important drops of water.

Fortunately, the same trade press that publishes Sendenkaigi and BRAIN also publishes books in which industry stars discuss such topics as how advertising differs from one medium to another, the implications of new media, how to manage creative teams, and how to develop and present creative ideas. Treating these authors as key informants helps to orient my thinking. To do justice to what they have written would, however, require another book.

In this essay, I turn to another source, the advertising contest annual published each year by the Tokyo Copywriters Club (TCC). Each year, several thousand ads are submitted to the TCC ad contest. Roughly ten percent of submissions survive the initial round of judging and appear in the annual. But the ads themselves are not my focus here.

The data for this paper are taken from the editors' introductions, judges' comments, and interviews with winners. They fascinate me because they have, for more than sixty years, provided an annual window on a long and still on-going debate. The debate is about a perennial issue: the roles of copy and copywriters in advertising. Following its ebb and flow reveals how economic fluctuations have changed the mood of the 
industry and the advent of new media, first TV, and now the Internet, have transformed the field in which copywriters and other advertising creatives do their creative work.

\section{Industry Background}

In 2009, when I first spoke to Maki Jun, one of Japan's most renowned copywriters, he remarked that during the 1970s putting together a creative team was still mainly a matter of meeting people in bars. By the 1980s, production companies had appeared. Assembling teams to produce TV commercials was one of their critical roles. During the1990s, the large agencies took control. Production companies and freelancers alike were dependent on the agencies.

I was thinking of what Maki had said as I read Amano Yukichi's Kōkoku mo kawatta ne [Advertising has also changed] (2008). As founder and editor of Kōkoku Hihyō [Advertising Critique] (1979-2009), Amano had closely tracked the history of advertising in Japan. He identifies three turning points.

The first was during the 1960s, as Japan's postwar economy took off. The Japanese advertising industry embraced marketing concepts imported from America, and advertising creatives were entranced by DDB's “Think Small," “Lemon," and other ads for Volkswagen. In them they saw models for advertising that could both be critical of contemporary society and create new markets.

The second turning point was during the 1980s, when TV, which had overtaken newspapers in share of advertising spend in 1975, became the dominant form of advertising in Japan. Instead of insights expressed in clever headlines designed to capture and hold the attention of newspaper and magazine readers, the new dominant form of ad was the 30 -second, and then increasingly 15-second, commercial. Action, music, and visual imagery captured audience eyeballs. The role of language was sharply reduced.

The 1990s were “the lost decade." Japan's economic bubble had collapsed. At this third turning point advertisers were cutting their budgets. A "return to basics" movement shaped advertising creative. Clever writing was still highly valued; but bean-counters increasingly demanded straight sales talk.

In the new millennium, Japan's economy remained sluggish, but new media-first satellite and cable TV, and then the Internet-appeared. When Amano shut down Kōkoku Hihyō in 2009, he explained that as advertising shifted away from broadcast TV, the ad world that he had known was finished. 


\section{The Tokyo Copywriters Club}

In November 1957. Yoshida Hideo, the president of Dentsu, Japan's largest advertising agency, invited 150 leading designers, art directors, and advertising photographers from all over Japan to a party at the Imperial Hotel to network and discuss the state of advertising in Japan. But only a bare handful of copywriters were invited, a slight that reflected their low status in the industry.

The Japan Advertising Artists Club (JAAC) had been formed six years earlier, in 1951. The Tokyo Art Directors Club (ADC) was already in formation. The copywriters lacked an organization of their own. In January 1958, a small group of copywriters founded the Kopii Tōkakai [Copy on the 10th Club].

The club started with seventeen members, who met on the 10th of each month to discuss the nature of copy and what copywriters could do to improve their professional status. By October 1961, when the third issue of Ten, the club newsletter, was published, the membership had risen to 84 . By then, the ADC had already begun publishing an annual, whose credits did not include copywriters. Copywriters in Japan were still being treated as assistants who need not be mentioned. The copywriters needed their own annual, and the club needed a new name.

"Kōpi Tōkakai" sounded too much like an informal, private association. A group claiming to be a professional association needed something more official sounding. Thus, in 1963, when it held its first contest and published its first annual, the club also changed its name to the Tokyo Copywriters Club (TCC).

\section{The debate begins}

The annual was launched as part of an effort to enhance copywriters' professional status. It did not, however, focus on copy alone. In the introduction, club founder Ueno Sofu argued that it made no sense to assert the old claim that "the copy is the advertising."

"Today's copywriter should start a step further back and accept the thinking that the problems of advertising copy are a part of the total advertising communication which integrates language and visual forms within a limited space." (TCC 1963: 1)

Ads selected for inclusion in the annual were judged as ads, creative concepts in which copy and visual work together.

\section{A decade later}

In the 1973 annual, the editors note that their theme, "Advertising and words," may seem commonplace. But, they write, copywriters face a new threat. 
"As we look at the copy in the last ten annuals, we see how step by step, copy and copywriters have been buried in organizations. Copywriters must retain their independence... Today's copywriters seem shackled. We see a danger here." (TCC 1973: 7)

In 1973, the rapid growth of Japan's economy during the 1960s had stalled. Clients were retrenching and less willing to embrace experimentation.

\section{The early eighties}

By 1980, Japan's economy was growing again. The copywriter's independence was still a major issue, but now the mood was optimistic.

"Neither the company's face. Nor the consumer's face. Copy fosters a third, independent face. Our own discoveries. Our own feelings. Our own sensibilities. Our own dreams. Our own words. We turn them into our own copy. Copy is always me, for as many different me's as there are copywriters." (TCC 1980: 1)

But good copy alone was not enough. In the 1981 annual, the editors write,

"When you just do it, that's nothing to brag about.

When you stand up and say, "I'll do it," that's a big deal.

Talent takes courage, talent takes guts.

To transcend everyday rhetoric, everyday feeling,

You have to be bold, sometimes you have to write nonsense." (TCC 1981: 1)

\section{The copywriter boom}

As economic growth accelerated during the early eighties, copy became almost literally magic. In 1982,

"One line of love, one line of infatuation,

One line of dreams, one line of tears, one line of youth, one line of promise,

One line of joking, one line of life, one line of miracles, one cosmic line.

Neither poet, nor novelist,

What works for the copywriter is a one-line love letter." (TCC 1982:

5)

In 1983,

"Everyone has a small god in his heart.

When we are most honest with ourselves,

The god will grant us an astonishing gift." (TCC 1983: i) 
This annual is, however, the twentieth in the series and, thus, a moment for reflection. Advertising legend Tsuchiya Koichi recalls that 1963 was a great year for gags, but also a year in which copy had a clear, decisive tone. By 1983, "Let's point our eyes at outer space" for Toshiba, or "Transistors have changed TV" for Sony, seem old-fashioned.

\section{The boom peaks}

In 1984, the copywriters are no longer seers, waiting on their gods. Creative genius is a talent, a gift.

"Delicious, cute, new, accurate, big, beautiful, amazing, outstanding...

The beautiful copy collected here attracted all these words of praise.

Every line is the finest flower of a copywriter's talent." (TCC 1984:

3)

In 1985, kansei, aesthetic sensitivity, had become a marketing buzzword. Functionality and product quality were taken for granted; products made in Japan were seen as the best in the world. Paradox was fascinating.

"Advertising copy is

An arena called kansei.

We are trying to be

Both soft and hard enough.

Our winners achieve this goal." (TCC 1985: 7)

In 1986, hubris filled the air. The annual's theme was "Hitmen." Copywriters were men (yes, almost entirely men) who turned products into hits. Editor-in-chief Okada Naoya posed in the nude. The art used in the annual was a pastiche of penises and pistols.

"Advertising is art.

But advertising is business as well.

Company, strategy, market, product.

Words, images, music, casting.

Pressures from all sides, and

The copywriter stands in the middle.

Conditions are hard, goals unclear.

That is why, all the more.

We can't be timid.

Unless we pull the trigger,

The advertising won't fire." (TCC 1986: 3)

Attention has shifted from copy, the art of producing magical words, to the copywriter, the man of the hour, tough, determined, unbowed, the one who pulls it all together. But the tide was already turning. 


\section{The boom is over}

By 1987, the copywriter boom had peaked. To Akiyama Sho, writing as jury chair, the relationship between copy and historical moment was neither the result of careful calculation nor the exercise of unstoppable genius. Serendipity, that's the word.

"We clap our hands, but which do we applaud?

The one on the right or the one on the left?

Great copy captures what people are thinking and feeling

In that year, that moment,

The copywriter and the mood of the moment

Are just right for each other." (TCC 1987: 23)

By 1988 only three years have passed since the "Hitmen" of 1985, but now the tone is plaintive.

"Writing good copy is a good thing; copywriters want to believe that." (TCC 1988: 3)

\section{What's in a name?}

In 1990, fifteen years after TV surpassed newspapers in share of advertising billings, the annual's name was changed from Kopì Nenkan [Copy Annual] to Kōkoku Nenkan [Advertising Annual], a change that remained in effect through 1999. Onoda Takao defended the change, likening it to a woman in her thirties choosing a new, more appropriate dress to replace what she had worn in her twenties. (TCC 1990: 7) Editorin-chief Nakahata Takashi complained that most of the prize winners were big campaigns. Great work in lesser formats like one-off magazine ads was being ignored. (TCC 1990: 9) Itoi Shigesato chose a campaign for Rolling-K, a cheap whiskey, which contained no copy at all, for the jury chair's prize. He likened copywriters to carpenters who no longer have to plane for themselves the wood used in the houses they build. (TCC 1990: 15).

In 1991, jury chair Maki Jun writes:

"The leading characteristic of this year's submissions was the shift from one-line to multi-line copy. Instead of single phrases, what we found were short poems like those found in collections of traditional Japanese poetry. Instead of trying to capture a message in a single, beautiful, powerful line, today's copywriters participate in "comprehensive proposals," "comprehensive decisions," "comprehensive executions." What a nuisance that is." (TCC 1991: 9) 


\section{The new regime}

In 1993, the editor is Sasaki Hiroshi, who during the next decade will, as copywriter or creative director, be associated with more award-winning ads than any other individual. Sasaki compares copywriters to Doraemon, the cartoon cat from the future, who always has something in his hyperspace pocket to bail out Nobita, a boy who is always getting into trouble. The Japanese business world is full of Nobitas, he says, clueless boys turning to copywriters and hoping to be handed some new device.

"The role of the copywriter has changed substantially. More than someone who just produces words, the copywriter is now expected to come up with concepts, to be a planner or creative director. On the positive side, the scope of the copywriter's job has broadened. On the negative side, it is often hard to tell what it is that we are supposed to do. The framework that defines our expertise seems in danger of collapsing. Be that as it may, here is what I think. It is wrong for copywriters to give up their role as the people who discover the right words... The words they come up with may not appear in print; they may be spoken or visualized instead. What we need to be are people who come up with big ideas, persuade others to adopt them, produce them and take responsibility for them." (TCC 1993: 6)

In 1996, three years later, Nakahata Takashi returns as jury chair and offers a different perspective.

"Advertising never says anything new. To communicate something radically new to our audience would be hugely expensive. To communicate efficiently, advertising creative should articulate the preconscious thoughts for which the audience has not yet found words. From this perspective, advertising creative is the product of what society is thinking." (TCC 1996: 8)

\section{And what will the future hold?}

Thirteen years later, in 2009, Japan's advertising industry is confronted with a global financial crisis and the rise of new technologies that disrupt its traditional business model. Nakahata is once again the jury chair.

"Corporations are on the defensive. One effect is a turn to realism. The preferred technique is to have a celebrity explain the product benefits. Advertising creative is an add-on to product features or corporate image. Thoughtfulness, playfulness, frankness, cuteness, depth, openheartedness, charm... Where are they? We see nothing but ads that show no affection for the audience."

His closing words reflect a growing pessimism,

"Would you buy anything from a salesman who shows not a bit of human feeling? Will you stop to listen to someone who is just 
running through a list of product features? Even selling snake-oil or hawking bananas provides a better service." (TCC 2009: 6)

\section{Looking Back to Look Forward}

Reviewing this brief account of the still on-going debate about the role of copy and copywriters, I ask myself what I see here that was missing in my previous attempts to write about advertising in Japan. I addressed issues raised by anthropological theory, but wrote in the ethnographic present. I ignored a vigorous trade press that had, ever since the early 1960s, been covering the industry in which I was interested.

In "Malinowski, Magic, and Advertising" (McCreery 1995), I noted that, while advertising resembles the symbols found in religion and magic, the latter value conformity and repetition of received models. In contrast, nothing is more damning when evaluating an ad concept, than to have someone say, "That's already been done." Advertising embraces change in a way that neither magic nor religion does.

In "Creating Advertising in Japan: a sketch in search of a principle" (McCreery 2001), I imagined a program of systematic research in which ethnographers working in different agencies pile up enough empirical cases to support a theory of how creativity works in Japanese advertising. Then, however, I noted that the number of possible ads and possible paths to reach them are, if not infinite, larger than the number of electrons in the visible universe. Predicting creative output seems, by definition, impossible. I argued that we can, nonetheless, explore the procedures by which ads are created, a series of familiar steps: orientation, brainstorming, preparing the presentation, the presentation, and, if all goes well and the client buys an idea, production of the finished ad.

I also suggested that Victor Turner's "social drama” (1974), Pierre Bourdieu's "habitus"(1992), and Brian Moeran's "tournament of value" (1996) offered theoretical perspectives from which to better understand this process. Here I would like to say a bit more about Turner's social drama.

Social dramas are conflicts in which perennial issues surface; individuals occupying different social positions align themselves with one side or another. The roles of copy and copywriters in advertising is a classic example. I cannot recall a single instance in the projects in which I participated while working at Hakuhodo in which this issue did not arise. Should a project start with copy or visual? Which should be given priority? Should the copy be long or short? Was copy even necessary? But focused on the job at hand, I ignored the historical moment in which I was working. I only gradually came to appreciate how differences in economic mood and medium, further constrained by product life cycles and client corporate culture, shaped what was possible in any particular case. Then, 
stepping back even further, I began to note how economic fluctuations and the advent of new technologies affected all these factors.

Considering what I learned required rethinking Turner. As a Manchester School social anthropologist trained by Max Gluckman, Turner assumed that perennial issues resulted in a cyclical process: rituals restored the status quo. As noted above, however, that is precisely where advertising diverges sharply from ritual as Turner conceived it. Every ad attempts a revolution, to change the world, if only a little because the status quo has been judged, from a business or critical perspective, to be unsatisfactory. Ritual attempts to deny history. Advertising embraces change. Creativity in advertising must, I now conclude, be examined and explained in historical context.

To combine anthropology with history is not, of course, a new idea. As I was revising this essay, I saw on the Internet that one of anthropology's most towering figures, Sidney Mintz, had died. The obituary in the Boston Review quoted Mintz, and no one ever said it better.

"Though I do not accept uncritically the dictum that anthropology must become history or be nothing at all, I believe that without history its explanatory power is seriously compromised. Social phenomena are by their nature historical, which is to say that the relationship among events in one "moment" can never be abstracted from their past and future setting." (Mintz 1985: xxx)

In turning to history, however, I see more than a methodological assumption. I see an opening for a new approach to business anthropology: By exploiting the wealth of historical information that an industry trade press makes available, we can identify perennial issues specific to particular industries. Industry-specific issues define the fields within which creativity occurs.

Having identified those issues, we can then go on to explore how economics and new technologies affect those fields. Here there is room to develop new theory to fill the gap between routine procedures that industry insiders take for granted and creativity's always unpredictable outcomes. Adding history to ethnography, we can engage in larger conversations. In the $\mathrm{C}$-suite as well as the academy.

\section{References}

Amano Yukichi. 2008. Kokoku mo kawatta,ne [Advertising, too, has changed]. Impress Japan.

Geertz, Clifford. 1968. Islam Observed: Religious Development in Morocco and Indonesia. Phoenix Books.

Marcus, George E. and Michael J. Fischer. 1999. Anthropology as Cultural Critique: An Experimental Moment in the Human Sciences. $2^{\text {nd }}$ edition. University of Chicago Press. 
McCreery, John. 1995. "Malinowski, magic and advertising: on choosing metaphor." In John Sherry, ed., Contemporary Marketing and Consumer Behavior: An Anthropological Sourcebook, pp. 309-329. Sage Publications.

McCreery, John, 2001. "Creating advertising in Japan: a sketch in search of a principle." In Brian Moeran, ed., Asian Media Productions, pp. 151-167. Curzon Press.

Mintz, Sidney. 1985. Sweetness and Power: The Place of Sugar in Modern Histor . Viking Elizabeth Sifton Books.

Moeran, Brian. 1996. A Japanese Advertising Agency: An Anthropology of Media and Markets. Curzon Press.

Moeran, Brian and Bo T. Christensen, eds. 2014. Exploring Creativity: Evaluative Practices in Innovation, Design, and the Arts. Cambridge University Press.

Tokyo Copywriters Club. 1963-present. TCC Kopii Nenkan [TCC Advertising Copy Annual]. Sendenkaigi. 